\title{
Outsourcing and Organizational Performance: A Comparative Analysis of Nigeria Bottling Company Plant and Camela Vegetable Oil Company, Owerri, Imo State, Nigeria
}

\author{
AUSTIN-EGOLE, Ifeyinwa Stella; IHERIOHANMA, E.B.J \\ Directorate of General Studies, Federal University of Technology, Owerri. \\ ifeyinwa.austin-egole@futo.edu.ng; ifyegole@yahoo.com \\ ekeoma.iheriohanma@futo.edu.ng; iherioha2005@yahoo.com
}

\begin{abstract}
Achievement of organizations' already set out goals and the level of attainment of those goals measure how successful the organizations are. They seek numerous strategies to help them in this quest. One of such strategies is outsourcing. Outsourcing is a management strategy where an organization delegates her major non-core functions to a specialized and efficient service provider enabling her to save both time and money. This research took a holistic look at outsourcing as a strategy and its effect on organizational performance using Nigeria Bottling Company Plant and Camela Vegetable Oil Company both situated in Owerri, Imo State as focal points. Core competency theory was used as theoretical framework. The survey research design was used, utilizing questionnaire and interviews as instruments of primary data collection. Library research was source of secondary data used for the analytical discussion. It was observed that outsourcing back office, primary and support activities have significant positive effect on organizational performance. The research therefore, recommends outsourcing as a strategy for improved performance in organizations.
\end{abstract}

Key words: Outsourcing, Organizational performance, Back office activities, Primary activities, Support activities, Core competency theory

DOI: $10.7176 /$ RHSS/10-12-09

Publication date:June 30th 2020

\subsection{Introduction and Background to the Study}

The growth of organizations ultimately results in the expansion of their activities. This growth in some instances tends to divert the organizations' focus from their core activities really needed to be done and might invariably affect the overall performance. To be able to avoid or better still reduce this loss of focus that might result in reduced or epileptic performance, there is need for the organizations to come to a decision to disengage their noncore activities in order to allow them have undivided focus on the more important and core tasks without sacrificing quality. This can be achieved through outsourcing. Outsourcing is a management tool that has gained relevance and acceptance among managers in addressing today's business dynamics (Jae, Minh, Kwok \& Shih, 2000). For Stroh and Treehuboff (2003), outsourcing is a management strategy where an organization delegates her major non-core functions to the specialized and efficient service provider, in turn saving time and money. According to Nwokocha and Iheriohanma's (2012) view on outsourcing, it grants organisations the daring opportunity to contract out non-core jobs to specialized firms and contractors at minimal or no cost and burden thus creating enough room for employees to be able to concentrate on the core activities in which they have competence and comparative advantage. In other words, outsourcing is basically the process of hiring a third party to do a job for the company, instead of having an in-house employee do the job.

Organizations consider outsourcing as a very important strategy required for sustenance in the current work environment because it plays a prominent role in improving performance by reducing costs, creating new products and services and equally enhancing quality and productivity (Jyoti, 2015). It is worthy of note that present day outsourcing is no more limited to non-core activities such as cleaning, catering and security but includes critical areas such as design, manufacturing, marketing, distribution, information system etc. (Jennings, 1997; Dominguez, 2006). A lot of notable international companies have been known to have outsourced parts of their job operations to other companies. Alibaba, one of the world's biggest global market-place started in China as a small internet company called China Yellow Pages. The organization was not only able to shoot to limelight in the international global market but equally optimized her performance. This was achievable, according to Shiying and Avery (2009), because Jack Ma, the founder of Alibaba, opted for outsourcing their website development to a US firm at a time when US developers were notably far advanced in the knowledge and skills Alibaba needed and was looking for as against the short supply of same obtainable in China. Sev (2009) avers that Kodak Company outsourced its computing operations to International Business Machines (IBM) and the outcome is higher quality computing system and operation at Kodak for less money than it was spending. In Nigeria, according to Sev (2009), in addition 
to Ashaka Cement Plc, which outsourced its operations and services to Blue Circle Industries of United Kingdom, several Nigerian mega banking groups like the United Bank for Africa (UBA) Plc. and Access Bank Plc. outsourced their Automated Teller Machines (ATM) to a company called Interswitch Operations to enhance global competition in the international financial markets. Some higher institutions of learning in Nigeria, for example, presently have given out cleaning of hostels, offices, etc. and even security to contracting firms; services which were hitherto carried out effectively by some sections or arms of the institutions and which were the beauty and attraction of campus life.

The fact that the organizations identified so far can be rated by all standards as big organizations, is not indicative that outsourcing is for just large organizations. Therefore, it is pertinent to point out that outsourcing is of different strategies as has been classified by different scholars in different ways (Agburu, Anza \& Iyortsuun, 2017) and is for all forms of organizations regardless of their size (whether small or large) (Isaksson \& Lantz, 2015), or type of outputs rendered whether manufacturing, information technology, services, product engineering, management services, and research process or marketing services (Suraju \& Hamed, 2013). Agranoff, (2006) posits that when organizations have managers with expertise in both contract management and the ability to handle issues of control and accountability, outsourcing can be a means of improving organization's performance.

The concept of organizational performance, is exceedingly broad and has been approached variously by experts in their quest to measure organizational performance (Amirkhanyan, Kim, \& Lambright, 2014; Andersen, Boesen, $\&$ Pedersen, 2016; Rainey, 2014). In the views of Agburu, et al (2017), organizational performance is the output of the organization, the fact notwithstanding whatever criteria used in getting at it. In other words, organizational performance could be summed up to be the process of achieving the organization's predetermined goals by increasing efficiency, quality, productivity, and profitability from the customer perspective as well as from the organizational perspective. Gilley and Rasheed (2000), posit four groups of outsourcing strategies related activities that can be utilized for improved organizational performance. These four strategies are outsourcing of: 1). Back office activities, 2). Primary activities, 3). Accounting activities, and 4). Support activities. These will be explained in details in the literature review. There have been tremendous research findings with different results on the effect of outsourcing strategy on organizational performance. While some like Gyemang, Aikins, Asibey \& Broni (2014), Suraju \& Hamed (2013), Nazeri, Gholami \& Rashidi (2012), Akewushola, and Elegbede (2013), Irefin, Olateju, \& Hammed (2012), Awolusi (2012) and Hayes, Hunton \& Reck (2000), presented a positive effect, Isaksson \&Lantz (2015), Yeboah (2013) and Gilley, Greer \& Rasheed (2004) posited that no effect or relationship was found between outsourcing and performance, it is noteworthy that upon how tremendous the level of research on the effect of outsourcing on organizational performance is, there is still paucity of such recorded research conducted in the continent of Africa generally and Nigeria in particular. Hence, there is the need to carry out more research in Nigeria to ascertain if the results obtained here will be in sync with those obtained in the developed and developing economies of the world.

Bearing in mind, that several companies are solidifying their outsourcing work while citing reduction in complexity, streamlining operations and increased efficiency as benefits, (Agburu, et al, 2017) and considering that some authors like Steensma and Corley (2000), Yalokwu (2006) and Dominguez (2006) reiterate that outsourcing can improve organizational performance when applied as an organizational strategy, this research seeks to conduct a comparative analysis of the effect of outsourcing strategies on the organisational performance of Nigeria Bottling Company Owerri - a multinational company using their operational plant in Imo State, Nigeria and Camela Vegetable Oil Company- an indigenous company equally situated in Owerri, Imo State Nigeria.

Considering that different outsourcing strategies have been shown to have divergent effects on organisational performance, the general question this research searches to answer is do Nigeria Bottling Company Owerri Plant and Camela Vegetable Oil Company outsource any of their activities in their efforts to improve performance? The specific questions include:

i. Does the outsourcing of back office activities affect performance in the organizations of study?

ii. What are the effects of outsourcing of primary activities on performance in the organizations of study?

iii. What is the contribution of outsourcing of support activities to the performance in the organizations of study?

iv. Do the organisations of study outsource their accounting activities?

The general objective of the paper is to examine if Nigeria Bottling Company (NBC) Owerri Plant and Camela Vegetable Oil Company outsource any of their activities in their efforts to improve performance. The specific objectives are to: 
i. Investigate if outsourcing of back office activities affects performance in the organizations of study.

ii. Evaluate the effect of outsourcing of primary activities on performance in the organizations of study.

iii. Investigate the contribution of outsourcing of support activities to the performance of the organizations of study.

iv. Ascertain if the organizations of study outsource their accounting activities.

\subsection{Hypotheses}

The following hypotheses are proposed:

Hypothesis 1: Outsourcing back office activities has a significant positive effect on organizational performance. Hypothesis 2: Outsourcing primary activities has a positive relationship with organisational performance.

\subsection{Outsourcing, Organizational Performance and Benefits: A Conceptual Review $2.1 \quad$ Outsourcing}

Organizations have set out goals they want to achieve and the level of attainment of those goals is how their success is measured. To be able to achieve these goals, they are always looking out for new strategies to enhance performance in this twenty first century era of advances in technology interwoven with sophistication in business processes, knowledge explosion and need for constant consistent growth (Dominguez, 2006). These new strategies could be in the form of outsourcing which involves focusing on their core competences while seeking to reduce operation cost (Akewushola and Elegbede, 2013). Outsourcing is a growing trend in work organisations in contemporary times. Organizations now outsource many activities that had been previously performed in-house by contracting out of a business function (Jae, et al. 2000; Dominguez, 2006; Isaksson and Lantz, 2015). Outsourcing non-core activities is believed by John (1999) to simultaneously free up human and capital resources in addition to allowing for increased flexibility in the way labour is employed. In critical terms, human resource capacity is reflected in the demographic makeup, specialization and expertise of the organization and care is taken to ensure its comfort and sustainability for productivity and performance.

Numerous definitions of outsourcing by different scholars abound. Outsourcing is an arrangement by which one company provides services to another company that could be or usually have been provided in-house. In other words, it is the transfer of some operations / functions to external service providers (Dibbern, Goles, Hirschheim, \& Jayatilaka, 2004) such that, authority is delegated to another party for the provision of services under a business contract that incorporates service level agreements related to cost, quality and timely delivery of product and service. Dominguez (2006) views outsourcing as the practice of hiring functional experts to handle operations that are outside of a firm's core business. In the long run, an agent external to the organization takes over the responsibilities pertaining to the management and development of innovations in outsourced activities. Yalokwu's (2006) definition of outsourcing as the process of subcontracting operations and services to other firms that specialize in such operations and services that can do them cheaper or better (or both) will suffice as the conceptual definition of outsourcing for this work. This definition avers that organizations have their areas of specialization. An organization that performs all its administrative and business services and operations may not perform all of them effectively and efficiently. This may lead to low quality products/services. When an organization focuses on areas that it has advantage comparatively and outsource those it performs minimally, this would lead to efficiency and high-quality product and performance.

The last two decades have recorded unprecedented growth in outsourcing (Kakabadse \& Kakabadse, 2002). Earlier before now, outsourcing originally focused on tactical benefits like cost reduction, quality, performance and enhancing core competencies but modern outsourcing now equally focuses on transformational outsourcing such as providing innovative ideas (Rebernik \& Bradac, 2006). This is because in the modern world, cost reduction has no meaning without innovation, which in turn leads to better performance for quality products (Rebernik \& Bradac, 2006). Considering TaskUs (2014) assertion that, what organizations do not have the resources to do, nor the know-how to do it well, nor the experience with the process at all but are trying to manage internally, will end up actually hurting the organization, embracing outsourcing which has turned out to be not only one of the most influential management tools, but equally the new frontier of modern business should be a welcome business strategy for every organization.

\subsection{Benefits of Outsourcing}

Over the years, outsourcing has been portrayed as a strategy with the aim of paving the way for organizations to be able to concentrate on their core competencies which promotes inter alia effectiveness and efficiency through 
reduced capital investment from cost savings within the firm, increased competition among suppliers, improved responsiveness to changes in the business environment, reduced risk of changing technology and ensuring higher quality goods and services in the future (Isaksson and Lantz, 2015; Dominguez, 2006; Jae, et al. 2000; Sev, 2009). Through outsourcing you can get expert and skilled services. Some scholars have reiterated the merits of expertise and creativity gained through outsourcing to external actors (Lindholst, Hansen, Randrup, Persson \& Kristoffersson, 2018; Van Slyke, 2009). This is attributable to the fact that outsourcing partners are specialized / specialists in that particular business process and as such more proficient services can be provided. Lindholst et al. (2018), posit that outsourcing enhances learning opportunities where the knowledge of and ideas for improved routines, methods, processes on how to undertake specialized tasks are transferred or made available from private contractors to organizations through contractual relations. Given relative autonomy imbibed in managing the partnership with contractors, organizations may be able to improve their productivity with new ideas and methods that facilitate better work process and innovation in their organization (Gyeo, Shinwoo, Deanna, \& Sergio, 2019).

Furthermore, private sector contractors are known for prioritizing customer satisfaction and as such employees of the hiring organization will be able to witness increasing responsiveness of those services and programmes and they will experience higher job satisfaction (Vrangbæk, Petersen \& Hjelmar, 2015). As organisations are using outsourcing to create space and time, employees are motivated to concentrate fully on their critical job and this makes for improved performance.

\subsection{Outsourcing Strategies}

Different scholars have classified outsourcing strategies in different ways. Gilley and Rasheed's (2000) classification which placed strategies into four groups housing related activities commonly outsourced will be reviewed in this study. These four strategies are:

1. Outsourcing of back office activities

2. Outsourcing of primary activities

3. Outsourcing of accounting activities

4. Outsourcing of support activities

Agburu et al, (2017) noted that Isaksson and Lantz (2015) fit in sixteen (16) sub activities commonly outsourced in the classification by Gilley and Rasheed (2000) based on their characteristics.

\section{From: Effect of outsourcing strategies on the performance of small and medium scale enterprises (SMEs)}

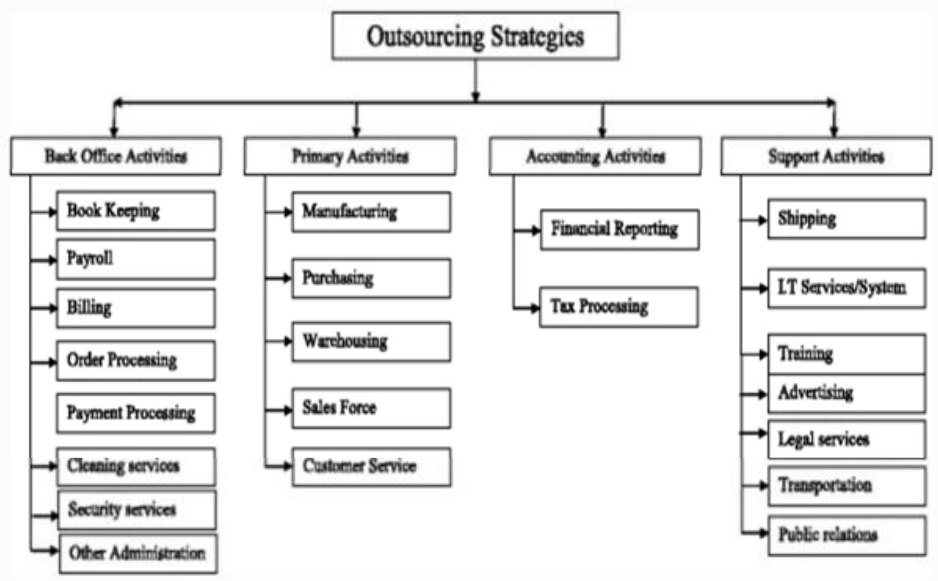

Classification of Outsourcing strategy according to Gilley and Rasheed (2000). Source: Base on the classification of outsourcing strategies by Gilley and Rasheed (2000); Isaksson and Lantz (2015)

Fig.1: Classification of Outsourcing Strategy

An improved version of these activities as presented by Agburu et al, (2017) is shown in Fig. 1 above.

1. Outsourcing of Back Office Activities: Back office activities are the non-core activities that an organization needs to make the day to day running of their office/business easier. As the name implies, back office refers to the functions which are very essential that they be carried out efficiently to ensure the success of the business, but are not part of the core operational functioning of the firm (Isaksson \& Lantz, 2015). Back-office 
operations are basically considered as the backbone of an enterprise and hence are not of less importance than the essential functions. Back office outsourcing has been on the rise in recent years not only because of how crucial they are to the core activities of any organization but also because of its many benefits which, according to Sev (2009), include: a) it allows for focus on core operations, b) outsourced job is carried out by professionals with domain expertise, c) it encourages higher level of flexibility, d) it paves way for access to state of the art technology and infrastructure, e) it induces lowered costs and, f) it reduces or totally eliminates the hassle for staff acquisition and retention. Back office activities as stated by Gilley and Rasheed (2000) include bookkeeping, billing, payroll, order processing and payment processing. Others are security services, cleaning services and other administrative activities which are essential to organizations for better service to their customers (Dominguez, 2006). When outsourced rightly, these back office activities have been shown to improve an organizations performance (Steensma \& Corley, 2000) by increasing quality, reducing costs and enhancing a firm's overall competitive position (Frayer, Scannell \& Thomas 2000). As explained earlier, in the education and health sectors and the hospitality industry in Nigeria, most universities, hospitals and hotels have outsourced cleaning, security and sundry services to firms for efficiency and to cut cost, thereby concentrating on their core mandate functions and application of core competence for competitive advantage.

2. Outsourcing of Primary Activities: The practice of outsourcing primary activities is attributable to the availability of resources and cost advantage. It is evident that many organisations are currently outsourcing even their primary activities. Nike, a prominent footwear manufacturer is a handy example. According to Agburu et al, (2017), Nike is renowned for the fact that it does not own any manufacturing facilities, but subcontracts out the manufacture of its products to independent suppliers. Isaksson and Lantz (2015) posit that the resource-based view of the organization and transaction cost economies gives a comprehensive explanation of the conditions that cause firms to resort to the outsourcing of primary activities and why such outsourcing strategy has grown in importance in recent years. Arguably, some organizations choose outsourcing of primary activities within their production chains to independent suppliers, not only because of relative capability considerations, but because they are able to use the high returns earned from their resources to set aside the rents incurred from the chain whilst reducing their asset base. Isaksson and Lantz (2015) highlight manufacturing, purchases, warehousing, sales force and customer service as activities directly related to the primary operations.

3. Outsourcing of Accounting Activities: Krell (2007) noted that such factors as competitive and budgetary pressures, advances in technology and communications and the need to transform the finance and accounting function prod organisations to strive to improve performance. Finance and accounting outsourcing (FAO), according to Hayward (2002), has undergone peculiar transformation over the years. He (Hayward, 2002), goes further to state that the market for finance and accounting outsourcing has matured with regards to the type of work embarked on whether normal routine work or customized higher-value complex services (such as forecasting and planning and treasury). Globalization of services equally opens up new opportunities for companies to outsource finance activities to service providers worldwide (Hayward, 2002). Kumaran (2013) points out that in contemporary times, organizations do not only try to assess cost effective solutions to systematically run non-core activities like accounting and payroll services, they equally expect to add value in order to achieve better control and understanding of cash flow and hence be able to make informed decisions. Though, accounting services are considered as non-core, they still form an integral part of an organization's operational capabilities and systematic functioning. Therefore, outsourcing accounting and payroll services, to Kumaran (2013), will be of help in further streamlining core business operations of an organization. Kumaran (2013) as cited in Agburu et al, (2017), further emphasized 10 top advantages of outsourcing accounting and payroll services to include: gaining from the assistance of experts, cost effective services, achieving high level of accuracy, fraud check, avoiding penalties during tax processing, reaping benefits with up-to-date technology, direct deposit through efficient payroll processing, saving up on processing time, avoiding reconciliation worries related to financial institutions and staying informed with up-to-date accounting status. Financial reporting and tax processing are noted by Isaksson and Lantz (2015) as some accounting activities typically performed by outside accountants.

4. Outsourcing of Support Activities: Support activities like back-office activities, according to Isaksson and Lantz (2015), aid in the efficient running of a business. They render support to the core activities in an organization (Sev, 2009). Support services enumerated by Isaksson and Lantz (2015) include shipping, advertising, IT services/system, training, public relations, legal services and transport services. Gilley and Rasheed (2000) classification of outsourcing activities is all encompassing and quite explicit. It highlights the activities which are being outsourced succinctly and classifies them based on their peculiarities. 


\subsection{Outsourcing and Organizational Performance}

While reviewing the relevance of outsourcing to organizational performance, it was observed that many authors amongst whom are Steensma and Corley (2000), Yalokwu (2006) and Dominguez (2006) submitted that, outsourcing can improve organizational performance when applied as an organizational strategy. Some of the numerous effects of outsourcing on organisational performance as highlighted by some authors are cited below. Dominguez (2006) avers that outsourcing one's business processes can improve the business' competitive edge and invariably improve performance; reason being that outsourcing, according to Yalokwu (2006), Dominguez (2006) and Kroes and Ghosh (2010), reduces business costs. By minimizing costs, organizations achieve their economic related goals and enhance their organizational performance (Leavy, 2004). This gives the organisation a competitive edge (Yalokwu, 2006) as the extra amount that would have been passed to the consumers in the form of higher prices for the goods and services now become irrelevant as consumers pay less for their commodities (Dominguez, 2006).

Through outsourcing, organizations minimize/eliminate whatever risks they would have faced from trying to balance between choosing the right alternatives in training their employees in that area of interest with regards to both huge infrastructural investment and spending huge amounts on replacing obsolete technology. The overall result, according to some scholars, is usually improvement in both concentration on core activities and overall performance and increased attraction of investors to these organizations (Yalokwu, 2006; Dominguez, 2006; Bustinza, Arias-Aranda \& Gutierrez-Gutierrez, 2010; Sev, 2006). According to Agburu et al, (2017), successful implementation of an outsourcing strategy has been shown to help cut cost (Gupta and Zheuder, 1994), increase cum improve capacity, quality, profitability, productivity, financial performance and organizational competitiveness (Steensma \& Corley, 2000; Kotabe, Murray, \& Javalagi, 1998) while simultaneously lowering both innovation costs and risks (Quinn, 2000). Nevertheless, Dominguez (2006) posits that outsourcing can equally generate some problems, since it usually reduces the organization's control over how certain services are delivered and this might raise the organization's liability exposure. This is more explained where the organization outsourcing and the contracting firm's focus, policy culture and strategy are seemingly at variance

A review of organizational performance literature uncovered disparities in the results obtained (Reio \& Kidd, 2006) which resulted from the variations in both the measuring variables of organizational performance and the types of studies (Reio \& Kidd (2006); Abbott, 2003; Huselid, 1995). Hence, organizational performance can be said to be measured in different ways depending on the intent. The level of employees' performance in a flexible working environment is measured by the degree of job satisfaction, productivity, customer satisfaction, employee commitment and retention (Austin-Egole, Iheriohanma \& Nwokorie, 2020; Onyeizugbe, Nduka \& Enaihi, 2019; Nwokocha \& Iheriohanma, 2012) as well as worker morale, turnover, level of satisfaction and absenteeism (Ying, 2012).

Exploring the relationship between job satisfaction, job performance and organizational performance implies the importance of employees to the organization. Reviews of research on organizational performance attest to the importance of employee perceptions of organizational performance as one of the key facets of this concept and a critical source of performance information (Andersen, Boesen, \& Pedersen, 2016; Boyne, 2002; Andrews, Boyne \& Walker, 2006). Understanding employee perceptions of organizational performance will advance our knowledge on both how employees perceive organizational performance and how valuable employee perceptions of organizational performance are because they are severally correlated with various antecedents of organizational performance. Research on employees' perceived image of their organization, including its values, mission, capacities, and performance have shown that the more positive the images, the more the employees are led to identify more strongly with their organization (Rho, Yun, \& Lee, 2015). Thus, knowledge of employee perceptions of performance can be used to infer something about employee behaviour and attitudes that influence organizational performance.

Though some early theorists of human relations had proposed that satisfied workers would be more productive, an earlier meta-analysis by Iaffaldano and Muchinsky (1985) indicated that the intensity of the job satisfaction performance relationship varies with regards to job aspects, and recorded divergent correlations, much lower for satisfaction with pay and higher with intrinsic features of the job. While elaborating more on this, both Brief and Weiss (2002) and Judge, Thoresen, Bono, \& Patton (2001) agree that improvements in the levels of energy, activity, and creativity, as well as memory and analytical abilities, all of which influence job satisfaction can positively affect performance. Furthermore, it has equally been severally noted that job satisfaction influences performance in a number of ways inter alia by and reducing turnover and absenteeism whilst increasing organizational commitment and favourable citizenship behaviour (Meyer, Stanley, Herscovitch, \& Topolnytsky, 2002; Cooper-Hakim \& Viswesvaran, 2005; Judge et al., 2001; Harrison, Newman, \& Roth, 2006). It would be 
added here that the job satisfaction - performance relationship uplifts / extols the employees' affective, normative and continuance commitment in the sense that the affective commitment indicates the employees' commitment on the basis of perception, inclination, choice and sustainability; the normative commitment unveils the employees' commitment on the basis of professional responsibility, legality and obligation; and, the continuance commitment relates to the employees' commitment to the organization and or job on the basis of absence of alternative and necessity. These three common factors underpin the relative relevance of human relations and human resource management practice in job / work related organizations anywhere.

\subsection{Empirical Review}

John (1999) reviewed existing research on four manufacturing companies in Australia, with the view of evaluating the effect of outsourcing on firm performance and employee commitment and found out that employee commitment among contractor employees is generally high, although it might take the organisation some years to realise the economic benefits. Gyeo, Shinwoo, Deanna, and Sergio (2019) posit that outsourcing has both modest negative effects on organizational performance as perceived by employees and equally influences perceived performance through its effect on job satisfaction. They (Gyeo et al, 2019) came about these postulations while testing a conceptual framework they developed using 5 years of panel data (2010-2014) from US federal agencies with the view of integrating and extending existing explanations on the effects of outsourcing on the government workforce and organizational performance.

While examining outsourcing services as a strategic tool for organizational performance in the Nigerian food, beverage, and tobacco industry, Suraju and Hamed (2013), using data obtained from questionnaire administered to a cross-section of 15 companies in food, beverage, and tobacco industry in Nigeria, as well as secondary data gotten from the files of statistical and fiscal declarations of these companies contained in the fact-book of Nigeria Stock Exchange (NSE) for the period of 2000-2010 concluded that organizational productivity is positively correlated to the amelioration of competitive advantage of labour productivity and average production cost and equally the more an organization outsourced, the higher its organizational growth. Furthermore, according to Agburu et al, (2017) the research went a step further to reveal that outsourcing is beneficial to organizational performance and enhances firm's financial economies and competitive advantage in the market place.

In the research work of Agburu, et al, (2017) to determine the effect of outsourcing strategies (back office activities, accounting activities, primary activities, and supporting activities) on the performance of Small and Medium Scale Enterprises (SMEs), they found out that outsourcing of back office activities, primary activities and supporting activities had shown significant effect on organizational profitability in contrast with outsourcing of accounting which showed no significant effect on performance of SMEs. In another research, Isaksson and Lantz (2015) found that there is no significant relationship between the outsourcing strategies (back office, primary, accounting and support activities) and financial performance measured in terms of return on investment (ROI) and return on equity (ROE). Isaksson and Lantz (2015) were able to arrive at that conclusion by using multiple regression to analyse data collected through a stratified sample of 700 small manufacturing firms in Sweden to find out how outsourcing strategies can be linked to financial performance (Return on Investment and Return on Equity) in small manufacturing firms.

Gyemang, Aikins, Asibey and Broni (2014) applied the descriptive approach which involved administering questionnaire to fifty (50) respondents made up of core management staff, key heads of departments and the main crew to find out the impact of outsourcing in the hotel industry in Ghana and concluded that most hotels outsource almost all of their non-core functions whilst concentrating on their core functions in the areas of accommodation, food and bar services and housekeeping. This research was however not explanatory on which outsourcing strategies were embarked upon by the organizations.

The relationship between outsourcing and organizational performance in the services sector was evaluated by Yeboah (2013) using SPSS to correlate the variables and data gotten from a population of 50 firms operating in the banking and insurance sectors of the economy of Ghana and the results were that there is firstly no statistically significant correlation between outsourcing and organizational productivity. Secondly, there is statistically significant correlation between outsourcing and quality and finally there is statistically significant correlation between outsourcing and competitive advantage. This research didn't put the effect of the strategy on organizational profitability into perspective.

Akewushola, and Elegbede (2013) examined the relationship between outsourcing strategy and organizational performance in Nigeria manufacturing sector using 120 sample elements derived from adopting a stratified sampling technique of some elevated managers of Cadbury Nigeria Plc and Nestle Foods Plc. Data analysis was 
with regression analysis and the result showed that firms with outsource experience had some advantages including reduced average cost, increased sales turnover and profitability, enhanced expertise, improved service quality, reduced staff strength, streamlined production processes, reduced administrative burden and saved time for core activities. This research though is limited to the manufacturing sector of Nigeria.

The results of the survey conducted by Nazeri, Gholami and Rashidi (2012), using SPSS and Minitab software based on deductive and descriptive statistics to examine the propensity to outsourcing and its impacts on operational objectives including cost reduction, improved quality, flexibility and better service and organizational performance, which includes financial performance and non-financial performance among the board of directors, quality managers, operational administrators, and lower managers indicated that outsourcing could lead to reduced cost, improved quality, increased flexibility, better financial and non-financial performance and services.

To establish the effect of outsourcing strategy on project success, Irefin, Olateju, and Hammed (2012) administered copies of questionnaire to staff of Nestle Nigeria PLC using stratified sampling techniques and equally interviewed some to authenticate the information derived. Results from data analysis using frequency distribution and ChiSquare indicated that firms outsourced their production process in order to manage cost, boost bottom line, reduce time-to-market, increase sales turnover and profitability, streamline the process, improve service quality, enhance expertise, reduce staff, reduce the administrative burden and save time for core activities. This research gives a very good background for the assessment of the effect their outsourcing activities had on the performance of their enterprises. It will serve as the bedrock upon which this research will be conducted to ascertain if similar results will be obtained.

An extensive meta-analysis of empirical studies on the link between performance and job satisfaction shows the two concepts to be correlated at about the .30 level, with higher correlations for more complex jobs (Judge, et al, 2001). Though, some researchers like Meier and O'Toole (2012) admonish against the use of perceptual measures of performance in public management research averring that such analysis reveals weak correlations between perceptual and objective measures of performance, with the former found to be distended and prone to producing false results. In a similar vein, Heneman (1986) had earlier shown in his meta-analysis report, a relatively weak correlation of .27 between perceptual and objective performance measures. However, a wide range of studies, including but not limited to Ketokivi and Schroeder (2003), Singh, Darwish, and Potočnik (2016) and Vij and Bedi (2016) revealed stronger correlations between these two types of performance measures. In short, while not interchangeable, employee perceptions of performance can be said to be sufficiently correlated with more objective measures to give one room to make reasonable inferences about how well an organization performs.

It can be observed from previous research findings as stated above that there are different results on the effect of outsourcing strategy on performance. While some like Gyemang, et al. (2014), Suraju \& Hamed (2013), Nazeri, Gholami \& Rashidi (2012), Akewushola, and Elegbede (2013), Irefin, Olateju \& Hammed (2012), Awolusi (2012), Hayes, et al. (2000), presented a positive effect, Isaksson \& Lantz (2015), Yeboah (2013) and Gilley, et al. (2004) posited that no effect or relationship was found between outsourcing and performance. In another vein, relatively few researches were conducted in underdeveloped economies like Nigeria as most of the researches recorded were carried out in relatively strong economies and developed nations. Hence, there is the need to carry out more research in Nigeria to ascertain if the results will still be obtained here as their findings cannot be imported and made to represent what is obtainable in a developing country/economy like Nigeria.

\subsection{Theoretical Framework: The Core Competency Theory}

Based on research findings over the years, researchers have theorized reasons and areas of outsourcing and its strategies. Prahalad and Hamel (1990) propounded the theory of core competency which believes that outsourcing of non-core areas is the best practice in utilizing resources (Prahalad \& Hamel, 1990; Dominguez, 2006; Jae, et al. 2000). Core competency as a theory is defined by Prahalad and Hamel (1990) as the collective learning, especially on how to coordinate diverse production skills and integrate multiple stream technologies in the organization. Core competency theory advocates that, the core activities of an organization should remain in house. As a theory of strategy, it prescribes that actions be taken by organizations to attain competitive advantage in the marketplace. Fundamentally, the concept of core competency avers that organizations must play to their strengths or those areas or functions in which they have competences. It is important for organizations to focus on their competences and draw their strengths from this when they want to get ahead of their competition. According to the Core Competence Model which was developed by Gary Hamel and C. K. Prahalad, organizations can move into new markets and market growth possibilities more easily by using their core competences. The reason to define core competences is the (specialized) available knowledge that is difficult to imitate by other organizations. By using its core competence an organization is capable of developing unexpected and surprising products provided that the 
production costs are low and that developments can be realized faster than those of the competition. There are more advantages to be obtained when core competence is applied to all organization-wide technologies and production skills. This will enable the organization to respond quickly and flexibly to a dynamic environment, based on using core competence. A core competency takes various forms. It could be in the form of having advanced technical/subject matter know-how or a reliable process and/or close relationships with customers and suppliers (Jae, et al. 2006). It equally includes product development or culture, such as best human resource management, employee dedication, good market coverage etc. Core competences are in summary those particular strengths and opportunities relative to other organizations in the industry which provide the foundation for the provision of added value.

Valuable organisation's resources are usually scarce, imperfectly imitable, and lacking in direct substitutes, so producing the most value from one's existing capabilities and resources by combining these with other sources of advantage and, in this, ensuring that complementarities is paramount. This theory is ideal as the theoretical framework of this study for many reasons. First, it advocates for organisations concentrating on their core activities while outsourcing the non-core ones. These core products are peculiar and associated best with their organizations and this makes them to be regarded as leaders in the area of such product offerings or delivery to customers. Secondly, the core competency theory is the theory of strategy that prescribes actions to be taken by firms to identify new opportunities, achieve competitive advantage in the marketplace and ultimately grow our business. The concept of core competency states that organizations must play to their strengths or those areas or functions in which they have competences. In addition, the theory also defines what forms a core competency and this has to do with it not being easy for competitors to imitate, it can be reused across the markets that the firm caters for and the services we can offer, and it must add value to the end user or the clients who get benefits from it. Hence, companies must focus on their strategies to tap into the core competences and the core competency is the fundamental basis for the value added by the firm. Finally, the main idea of this theory is enhancing the core competence of the company in order to develop sustainable competitive advantage, which outsourcing is positioned to achieve (Jae, et al. 2006). Essentially, organizations contract out not only non-core activities but activities they have weaknesses and threats and concentrate on those they have strengths and opportunities (SWOT analysis).

\section{Methodology}

\subsection{Area of Study}

The study was conducted at the Owerri Plant of the Nigerian Bottling Company Plc and Camela Vegetable Oil Company Limited, Owerri. Both companies are located at the New Industrial Layout, Onitsha Road, Owerri, Imo State, Nigeria and are primarily concerned with production of goods. The Nigeria Bottling Company (NBC) Plc, Nigeria's largest bottler of non-alcoholic beverage was incorporated in 1951 as a bottling subsidiary of A.G. Leventis Group with the sole franchise to bottle and sell Coca-Cola products in Nigeria. Production in Coca-Cola began in 1953 at a bottling facility in the basement of Mainland Hotel, Lagos. Over the years, NBC has grown from just one bottling plant to 14 plants, over 82 depots and numerous sales outlets nationwide. NBC became a public company in 1972 and has its shares listed on the Nigerian Stock Exchange. In 2000, it became a member of the Coca-Cola Hellenic Bottling Company Group operating in 26 countries world - wide. Their products range includes Coca-Cola, Fanta, Sprite, Schweppes, Eva water, Five Alive Fruit Juice and Cappy Fruit Juice.

The Camela Vegetable Oil Company Limited was incorporated in 1960 in the name of R. O. Ikoro \& Sons Limited as a private company dealing in agricultural produce and oil milling. Owing to new business opportunities pursued by the Company, in 1985, activities were expanded to include the extraction of palm kernel oil and palm kernel cake. There was a major expansion to include the processing of vegetable oil with the production of fatty acid as a by-product under a new name of Camela Vegetable Oil Company Limited. Consequently, the name of the Company was changed from R. O. Ikoro \& Sons Ltd to Camela Vegetable Oil Company Limited in August 2000. The Company is involved in the production of palm kernel oil and palm kernel cake. While the palm kernel cake is sold to producers of animal feed and solvent extractors, the palm kernel oil is further processed to produce a vegetable oil; as Camela Vegetable Oil and fatty acid which are sold to soap producers.

\subsection{Organizational Structure of the Companies}

The plant manager heads the affairs of the NBC Plc Owerri plant. Underneath him are the managers of different departments like Commercial, Finance, HR, Production, Safety, Information system and Logistics. After the departmental managers we have the sales representatives, salesmen and other staff.

For the Camela Vegetable Oil Company Owerri, the Board of Directors handles the affairs of the Company. Directly below them is the Chairman/Managing Director, followed by the Executive Director, General Manager 
and Assistant General Manager. Others include the Financial Controller, Marketing Manager, Administration Manager, Production Manager, Shift Supervisors (maintenance and production), cleaners, gardeners, drivers etc.

\subsection{Population and Sampling Procedure}

The methodology adopted in this investigation is the survey research design. The population of the staff of Nigeria Bottling Company is 804 (404 permanent and 400 temporary) while Camela Vegatable is 120. (See Table 1). Both are used as population of study. The entire population of Camela Vegetable Oil Company Ltd which is 120 was studied because the population was considered not too large; hence, there was no need for a representative sample. However, for the NBC, both the permanent and temporary staff were sampled. The decision to include the temporary staff was taken because casualization of workers or the emergence of contingency workers is one of the emerging work trends. Three quarters $(3 / 4)$ of the permanent staff population which is 303 and half $(1 / 2)$ of the temporary staff population which is 200 , amounting to 503 was sampled and it is regarded as representative of the staff population of 804. Questionnaire and interview were utilized as instruments of primary data collection. Multistage sampling involving stratified, quota and random sampling methods were adopted to ensure that respondents were gotten from all the departments in the organization and that the number of respondents administered questionnaire in the different departments is representative of their percentage in the entire population. Eleven (11) heads of the various departments of both organizations were interviewed (the heads of six departments in NBC Plc and those of five departments of Camela Vegetable Oil Company Ltd). Hence the chosen sample size for this study was 120 plus 503 plus 11 interviewees amounting to 634 respondents. The questionnaire was divided into two sections. Section A involved the socio-demographic variables of the respondents while Section B comprised questions relating to the different outsourcing strategies as they relate to the organizational performance of Nigeria Bottling Company Plc Owerri and Camela Vegetable Oil Company Owerri. The Likert 5point scale was used in the construction of close-ended questions to facilitate easy interpretation. The options are weighted as follows:

$\begin{array}{lll}\text { i. } & \text { Strongly agree } & 5 \\ \text { ii. } & \text { Agree } & 4 \\ \text { iii. } & \text { Undecided } & 3 \\ \text { iv. } & \text { Disagree } & 2 \\ \text { v. } & \text { Strongly disagree } & 1\end{array}$

Close-ended questions were used to ensure reliability. The questionnaire was self-administered at about noon on a working day through the heads (morning and night duties) of the various departments to reduce the incidence of un-returned questionnaire and to ensure that the opinions of employees on night shift were also gotten. Secondary data were gathered from text books and journals. Interview guide was developed for soliciting information from the interviewees.

Table 1: Population of Employees of Nigerian Bottling Company Owerri Plant and Camela Vegetable Oil Company According to Departments

\begin{tabular}{|l|l|l|l|l|}
\hline Department & NBC Permanent & NBC Temporary & Total & CAMELA \\
\hline Production & 138 & 193 & 331 & 62 \\
\hline Haulage & 20 & 34 & 54 & - \\
\hline Administration & - & - & & 24 \\
\hline Warehousing \& Distribution & 33 & 61 & 94 & - \\
\hline Sales \& Marketing & 167 & 103 & 270 & 12 \\
\hline Finance & 30 & - & 27 & 12 \\
\hline HR & 16 & 9 & 20 & 10 \\
\hline Total & 404 & 400 & 804 & 120 \\
\hline
\end{tabular}

Source: NBC Employee's Distribution Chart from CCHBC Nigeria Intranet and Camela Vegetable Oil Company's Corporate Profile.

Table 1 above shows the population of Nigeria Bottling Company Owerri Plant and Camela Vegetable Oil Company. It represents the different departments and the number of employees in each department. 
Table 2: Stratified / Quota Sampled Size for NBC Plc Owerri

\begin{tabular}{|l|c|c|c|}
\hline Departments & Permanent & Temporary & Total \\
\hline Production & 104 & 97 & 201 \\
\hline Haulage & 15 & 17 & 32 \\
\hline Warehousing \& Distribution & 27 & 30 & 57 \\
\hline Finance & 20 & - & 20 \\
\hline HR & 12 & 5 & 17 \\
\hline Sales \& Marketing & 125 & 51 & 176 \\
\hline Total & 303 & 200 & 503 \\
\hline
\end{tabular}

Source: Field Work, 2019

Table 2 above shows the stratified/quota sampled size from the departments of NBC for the study.

\subsection{Method of Data Analysis}

The technique for quantitative data analysis was the percentage distribution which was used to determine the proportion of respondents choosing the various responses. The chi-square $\left(x^{2}\right)$ statistics was used to test the hypotheses of the study. The chi-square $\left(x^{2}\right)$ technique is a test of independence, the idea that one variable is not affected by another variable. It is a test of association, used to compare differences between observed and expected frequencies. It is given by the formula:

$$
x^{2} \quad=\frac{\sum(0-\mathrm{E})}{\mathrm{E}}
$$

Where:

$$
\begin{aligned}
& x^{2}=\text { Chi-squared } \\
& \sum=\text { Sum Of } \\
& \mathrm{E}=\text { Expected frequency } \\
& \mathrm{O}=\text { Observed frequency } \\
& \text { consideration was given to the } \\
& \text { calculated using the formula: } \\
& \mathrm{df}=(\mathrm{r}-1)(\mathrm{c}-1) \text { (Kelley and } \\
& \text { Where } \\
& \mathrm{df}=\text { degree of freedom } \\
& \mathrm{r}=\text { number of rows } \\
& \mathrm{c}=\text { number of columns }
\end{aligned}
$$

$\mathrm{O}=$ Observed frequency (Kelley and Donnelly, 2009). In testing the significance of the chi-square $\left(x^{2}\right)$, due consideration was given to the degree of freedom and the level of significance. The degree of freedom (df) is

$\mathrm{df}=(\mathrm{r}-1)(\mathrm{c}-1)($ Kelley and Donnelly, 2009)

Where

Interview responses were analyzed thematically.

\section{4: Data Presentation, Analysis and Discussion of Findings}

"PER" and "TEM" as used in subsequent tables represent respondents from the permanent and temporary staff of NBC Plc Owerri while TOT and NO. represent total and number respectively. Copies of returned questionnaire were 508 representing $93 \%$. This was a high return rate and the analysis of data collected was made based on this figure of returned questionnaire. 
Table 3: Background Characteristics of Respondents

\begin{tabular}{|c|c|c|c|c|c|c|c|c|c|c|c|c|c|}
\hline & & \multicolumn{6}{|c|}{ NBC PLC } & \multicolumn{2}{|c|}{ CAMELA } & \multicolumn{2}{|c|}{ SEX } & \multicolumn{2}{|c|}{ TOTAL } \\
\hline CATEGORY & OPTION & PER & $(\%)$ & TEM & (\%) & TOT & $(\%)$ & No. & $(\%)$ & $\mathbf{M}$ & $\mathbf{F}$ & Total & $(\%)$ \\
\hline \multirow[t]{3}{*}{ Sex } & Male & 220 & 77.5 & 70 & 37.6 & 290 & 61.7 & 80 & 72.7 & 370 & - & 370 & 63.8 \\
\hline & Female & 64 & 22.5 & 116 & 62.4 & 180 & 38.3 & 30 & 27.3 & - & 270 & 210 & 36.2 \\
\hline & TOTAL & 284 & 100 & 186 & 100 & 470 & 100 & 110 & 100 & 370 & 210 & 580 & 100 \\
\hline \multirow[t]{6}{*}{ Age } & 20\& Below & 62 & 21.8 & 59 & 31.7 & 121 & 25.7 & - & - & 91 & 30 & 121 & 20.9 \\
\hline & $21-30$ & 91 & 32.0 & 83 & 44.6 & 174 & 37.1 & - & - & 92 & 82 & 174 & 30.0 \\
\hline & $31-40$ & 90 & 31.7 & 44 & 23.6 & 134 & 28.5 & 70 & 63.6 & 127 & 77 & 204 & 35.2 \\
\hline & $41-50$ & 30 & 10.6 & - & - & 30 & 6.4 & 20 & 18.2 & 40 & 10 & 50 & 8.6 \\
\hline & Above 50 & 11 & 3.9 & - & - & 11 & 2.3 & 20 & 18.2 & 20 & 11 & 31 & 5.3 \\
\hline & TOTAL & 284 & 100 & 186 & 100 & 470 & 100 & 110 & 100 & 370 & 210 & 580 & 100 \\
\hline \multirow[t]{3}{*}{ Marital Status } & Single & 131 & 46.1 & 59 & 31.7 & 190 & 40.4 & 10 & 9.1 & 119 & 81 & 200 & 34.5 \\
\hline & Married & 153 & 53.9 & 127 & 68.3 & 280 & 59.6 & 100 & 90.9 & 251 & 129 & 380 & 65.5 \\
\hline & TOTAL & 284 & 100 & 186 & 100 & 470 & 100 & 110 & 100 & 370 & 210 & 580 & 100 \\
\hline \multirow[t]{9}{*}{ Departments } & Production & 101 & 35.6 & 95 & 51.1 & 196 & 41.8 & 60 & 54.5 & 152 & 104 & 256 & 44.1 \\
\hline & Haulage & 12 & 4.2 & 14 & 7.5 & 26 & 5.5 & - & - & 26 & - & 26 & 4.5 \\
\hline & Warehousing & 23 & 8.1 & 26 & 13.9 & 49 & 10.4 & - & - & 35 & 14 & 49 & 8.5 \\
\hline & Finance & 18 & 6.3 & - & - & 18 & 3.8 & 10 & 9.1 & 19 & 9 & 28 & 4.8 \\
\hline & HR & 11 & 3.9 & 4 & 2.2 & 15 & 3.2 & 8 & 7.3 & 14 & 9 & 23 & 3.9 \\
\hline & Sales & 119 & 41.9 & 47 & 25.3 & 166 & 35.3 & 10 & 9.1 & 112 & 64 & 176 & 30.4 \\
\hline & Admin. & - & & - & - & - & - & 22 & 20.0 & 12 & 10 & 22 & 3.8 \\
\hline & TOTAL & 284 & 100 & 186 & 100 & 470 & 100 & 110 & 100 & 370 & 210 & 580 & 100 \\
\hline & & \multicolumn{6}{|c|}{ NBC PLC } & \multicolumn{2}{|c|}{ CAMELA } & $\mathbf{M}$ & $\mathbf{F}$ & \multicolumn{2}{|c|}{ TOTAL } \\
\hline \multirow{6}{*}{$\begin{array}{l}\text { Highest Educational } \\
\text { Qualification }\end{array}$} & FSLC & - & - & 9 & 4.8 & 9 & 1.9 & - & - & 6 & 3 & 9 & 1.6 \\
\hline & WASC/GCE & - & - & 58 & 31.2 & 58 & 12.3 & 30 & 27.3 & 59 & 29 & 88 & 15.2 \\
\hline & NCE/OND & 43 & 15.1 & 50 & 26.9 & 93 & 19.8 & - & - & 49 & 44 & 93 & 16.0 \\
\hline & B.Sc/HND & 212 & 74.7 & 61 & 32.8 & 273 & 58.1 & 70 & 63.6 & 229 & 114 & 343 & 59.1 \\
\hline & M.Sc/Ph.D & 29 & 10.2 & 8 & 4.3 & 37 & 7.9 & 10 & 9.1 & 27 & 20 & 47 & 8.1 \\
\hline & TOTAL & 284 & 100 & 186 & 100 & 470 & 100 & 110 & 100 & 370 & 210 & 580 & 100 \\
\hline \multirow{6}{*}{$\begin{array}{l}\text { Number of Years of } \\
\text { Service }\end{array}$} & Less than 1 & - & - & 48 & 25.8 & 48 & 10.2 & 10 & 9.1 & 35 & 23 & 58 & 10.0 \\
\hline & $1-2$ & 36 & 12.7 & 79 & 42.5 & 115 & 24.5 & 20 & 18.2 & 92 & 43 & 135 & 23.3 \\
\hline & $3-5$ & 205 & 72.2 & 59 & 31.7 & 264 & 56.2 & 40 & 36.3 & 190 & 114 & 304 & 52.4 \\
\hline & $6-10$ & 32 & 11.2 & - & - & 32 & 6.8 & 10 & 9.1 & 25 & 17 & 42 & 7.2 \\
\hline & Above 10 & 11 & 3.9 & - & - & 11 & 2.3 & 30 & 27.3 & 28 & 13 & 41 & 7.1 \\
\hline & TOTAL & 284 & 100 & 186 & 100 & 470 & 100 & 110 & 100 & 370 & 210 & 580 & 100 \\
\hline \multirow{3}{*}{$\begin{array}{l}\text { Type of } \\
\text { Employment } \\
\text { Contract }\end{array}$} & Permanent & 284 & 100 & - & - & 284 & 60.4 & 110 & 100 & 212 & 182 & 394 & 67.9 \\
\hline & Temporary & - & - & 186 & 100 & 186 & 39.6 & - & - & 158 & 28 & 186 & 32.1 \\
\hline & $\begin{array}{l}\text { TOTAL } \\
\end{array}$ & 284 & 100 & 186 & 100 & 470 & 100 & 110 & 100 & 370 & 210 & 580 & 100 \\
\hline
\end{tabular}

Source: Field work, 2019 
Table 3 above reveals that a greater percentage of the respondents, $63.8 \%$, are males, while $36.2 \%$ are females. Those 20 years and below are $20.9 \%$ of the respondents while $5.3 \%$ are above 50 years. Majority of the respondents (35.2\%) are within the 31- 40 years age bracket implying that most of the employees are in their youth. The age analysis equally shows that whereas the NBC Plc Owerri has no temporary staff above the age of 40, Camela Vegetable Oil Company Ltd Owerri on her part has no staff below the age of 30. The percentage of respondents that are single is $34.5 \%$, while those that are married are $65.5 \%$. It is of note that NBC Plc has no temporary staff in her finance department. This could be as a result of the amount of risk involved in sending a staff whose employment contract has no guaranteed security to such a sensitive department. The Camela Vegetable Oil Company Ltd on its part has no warehousing department and as such no staff allotted to that department. This, according to some interviewees, is owing to the fact that most of the products are always booked before production hence they are delivered to those that booked them immediately after production. This, it is argued, is because Camela Vegetable Oil Company Ltd is yet to attain optimal productivity level. If it has, it will have warehouses for storage of finished products before sales and distribution. This may in turn impact negatively on their level of sales and profits because buyers will have to wait for goods to be produced before being supplied as against produced goods being always available for sales. Those that have worked below a year in the organizations make up $10 \%$ of the respondents while those who have worked above 10 years make up $7.1 \%$. It should be noted that those who have worked between 3-5 years make up the greatest percent at 52.4\% which implies that there was a relatively high level of employment into this organization within the last 3-5years. The percentage of respondents who possess higher degrees (M.Sc. and Ph.D) is $8.1 \%$ while those with First School Leaving Certificate (FSLC) constitute a meagre $1.6 \%$ of the respondents. Furthermore, the fact that a greater percentage of the respondents of both organizations, 59.1\%, have either a Bachelor of Science (B.Sc) degree or Higher National Diploma (HND) certificate shows that these organizations are aware of the relevance of knowledge and knowledge workers to the attainment of effective and efficient productivity in an organization. In the area of employment contract, it is only the NBC that has temporary staff and this constitutes $39.6 \%$ of the respondents from that organization and $32.1 \%$ of the total respondents. The permanent employees of the two organizations represent $67.9 \%$ of the total respondents.

Table 4: Responses on Whether the Organizations Outsource Some of their Activities

to Improve

\begin{tabular}{|l|l|l|l|l|l|l|l|l|l|l|}
\hline & \multicolumn{9}{|c|}{ NBC PLC } & \multicolumn{3}{l|}{ CAMELA } & \multicolumn{2}{c|}{ TOTAL } \\
\hline \multicolumn{1}{|c|}{ Options } & PER & $\%$ & TEM & $\%$ & TOT & $\%$ & NO. & $\%$ & TOT & $\%$ \\
& & & & & & & & & \\
\hline Strongly Agree & 81 & 28.5 & 75 & 40.3 & 156 & 33.2 & 33 & 30.0 & 189 & 32.5 \\
& & & & & & & & & & \\
\hline Agree & 127 & 44.7 & 55 & 29.5 & 182 & 38.7 & 53 & 48.2 & 235 & 40.5 \\
\hline Undecided & 22 & 7.7 & 9 & 5.0 & 31 & 6.7 & 7 & 6.4 & 38 & 6.7 \\
\hline Disagree & 22 & 7.7 & 41 & 22.0 & 63 & 13.4 & 8 & 7.2 & 71 & 12.2 \\
\hline Strongly Disagree & 32 & 11.3 & 6 & 3.2 & 38 & 8.0 & 9 & 8.2 & 47 & 8.1 \\
\hline TOTAL & $\mathbf{2 8 4}$ & $\mathbf{1 0 0}$ & $\mathbf{1 8 6}$ & $\mathbf{1 0 0}$ & $\mathbf{4 7 0}$ & $\mathbf{1 0 0}$ & $\mathbf{1 1 0}$ & $\mathbf{1 0 0}$ & $\mathbf{5 8 0}$ & $\mathbf{1 0 0}$ \\
\hline
\end{tabular}

Source: Field work, 2019

From Table 4, 73.2\%, 69.8\% and 78.2\% of the respondents from the permanent and temporary staff of NBC Plc and Camela Vegetable Company Ltd respectively agree that their organizations outsource some of their activities to other organizations. On the whole, $73 \%$ of the respondents agree that their organizations outsource some of their activities, $20.3 \%$ disagree, while $6.7 \%$ are undecided. This is in consensus with the opinions of the interviewees from both organizations. This shows that outsourcing, a recent growing trend in contemporary times is being harnessed for improved performance. Its implication is that employees will be able to concentrate on the jobs they know best and performance will be sustained. According to one of the senior officers / heads of department in NBC:

"We contract out some of our activities such as transportation, cleaning, security, etc. to some other organizations / companies to allow us concentrate on our major jobs". (Male, HOD, NBC, Aged 47). 
Table 5: Responses on whether the Outsourcing of Back Office Activities Positively Affect Organizational Performance

\begin{tabular}{|l|l|l|l|l|l|l|l|l|l|l|}
\hline & \multicolumn{9}{|c|}{ NBC PLC } & \multicolumn{2}{l|}{ CAMELA } & \multicolumn{2}{c|}{ TOTAL } \\
\hline \multicolumn{1}{|c|}{ Options } & PER & $\%$ & TEM & $\%$ & TOT & $\%$ & NO. & $\%$ & TOT & $\%$ \\
\hline Strongly Agree & 175 & 61.6 & 50 & 26.9 & 225 & 47.9 & 39 & 35.4 & 264 & 45.5 \\
& & & & & & & & & & \\
\hline Agree & 65 & 22.9 & 71 & 38.2 & 136 & 28.9 & 31 & 28.2 & 167 & 28.8 \\
\hline Undecided & 30 & 10.6 & 39 & 20.9 & 69 & 14.6 & 18 & 16.4 & 87 & 15.0 \\
\hline Disagree & 4 & 1.4 & 16 & 8.6 & 20 & 4.3 & 14 & 12.7 & 34 & 5.9 \\
\hline Strongly Disagree & 10 & 3.5 & 10 & 5.4 & 20 & 4.3 & 8 & 7.3 & 28 & 4.8 \\
\hline TOTAL & $\mathbf{2 8 4}$ & $\mathbf{1 0 0}$ & $\mathbf{1 8 6}$ & $\mathbf{1 0 0}$ & $\mathbf{4 7 0}$ & $\mathbf{1 0 0}$ & $\mathbf{1 1 0}$ & $\mathbf{1 0 0}$ & $\mathbf{5 8 0}$ & $\mathbf{1 0 0}$ \\
\hline
\end{tabular}

Source: Field work, 2019

Table 5 reveals that there is a general agreement from both organizations that outsourcing back office activities improve performance. About 76.8\% of respondents from NBC Plc and 63.6\% of respondents from Camela Vegetable Oil Company Ltd are in agreement. On the other hand, about 8.5\% of the respondents from NBC Plc and 20\% from Camela Vegetable Oil Company Ltd disagree. In all, $74.3 \%$ of the respondents are in agreement that outsourcing of back office activities positively affects organizational performance. This is in consonance with the opinions of the interviewees from both organizations. The head of human resource department of NBC, a 45 years old male pointed out that back office activities outsourced include cleaning and security services. In his words:

"My organization gives out the cleaning, security and sundry activities to allow us perform and serve our stakeholders efficiently". (Male, HOD, HRM, NBC, 45yrs.)

This implies that there is general awareness of the importance of outsourcing back office activities on improved performance in contemporary work organizations.

Table 6: Responses on whether Outsourcing Primary Activities Affects Organizational Performance

\begin{tabular}{|l|l|l|l|l|l|l|l|l|l|l|}
\hline & \multicolumn{9}{|c|}{ NBC PLC } & \multicolumn{3}{l|}{ CAMELA } & \multicolumn{2}{c|}{ TOTAL } \\
\hline \multicolumn{1}{|c|}{ Options } & PER & $\%$ & TEM & $\%$ & TOT & $\%$ & NO. & $\%$ & TOT & $\%$ \\
\hline Strongly Agree & 88 & 30.9 & 18 & 9.6 & 106 & 22.5 & 27 & 24.5 & 133 & 22.9 \\
& & & & & & & & & & \\
\hline Agree & 152 & 53.5 & 124 & 66.7 & 276 & 58.7 & 33 & 30.0 & 309 & 53.2 \\
\hline Undecided & 26 & 9.3 & 14 & 7.6 & 40 & 8.7 & 20 & 18.3 & 60 & 10.5 \\
\hline Disagree & 4 & 1.4 & 17 & 9.1 & 21 & 4.4 & 14 & 12.7 & 35 & 6.0 \\
\hline Strongly Disagree & 14 & 4.9 & 13 & 7.0 & 27 & 5.7 & 16 & 14.5 & 43 & 7.4 \\
\hline TOTAL & $\mathbf{2 8 4}$ & $\mathbf{1 0 0}$ & $\mathbf{1 8 6}$ & $\mathbf{1 0 0}$ & $\mathbf{4 7 0}$ & $\mathbf{1 0 0}$ & $\mathbf{1 1 0}$ & $\mathbf{1 0 0}$ & $\mathbf{5 8 0}$ & $\mathbf{1 0 0}$ \\
\hline
\end{tabular}

Source: Field work, 2019

Table 6 reveals a general consensus on the organizations outsourcing primary activities and this improves performance in both organizations. About $84.4 \%$ and $76.3 \%$ of the permanent and temporary staff respectively of NBC Plc and $54.5 \%$ of respondents from Camela Vegetable Oil Company Ltd agree that outsourcing of primary activities improves organizational performance. In total $76.1 \%$ of the respondents agree, $13.4 \%$ disagree and $10.5 \%$ are undecided. This shows that an organization's performance level can be enhanced by outsourcing the primary activities. A male interviewee in NBC had this to say:

"NBC outsources the production of all bottles, pet coke, water and juice". (Male, Head of Production, NBC, 48 years old).

For Camela Vegetable Company, the Head of Production averred that fabrication is outsourced. According to him: "Our organization contracts out the fabrication activities, such as the plastic cans and the like. This has helped us realize high returns unlike when we did all these in-house". (Male Head, Production, Camela, Aged 44).

It implies that outsourcing of primary activities allows organizations get high returns while being able to meet contemporary market challenges. It can be said that these companies are harnessing the benefits accruable from this contemporary work trend. 
Table 7: Responses on Whether Outsourcing Support Activities Contribute to Improved Organizational Performance

\begin{tabular}{|l|l|l|l|l|l|l|l|l|l|l|}
\hline & \multicolumn{9}{|c|}{ NBC PLC } & \multicolumn{2}{c|}{ CAMELA } & \multicolumn{2}{c|}{ TOTAL } \\
\hline \multicolumn{1}{|c|}{ Options } & PER & $\%$ & TEM & $\%$ & TOT & $\%$ & NO. & $\%$ & TOT & $\%$ \\
\hline Strongly Agree & 104 & 36.6 & 38 & 20.4 & 142 & 30.2 & - & - & 142 & 24.5 \\
& & & & & & & & & & \\
\hline Agree & 37 & 13.0 & 21 & 11.3 & 58 & 12.3 & 9 & 8.1 & 67 & 11.5 \\
\hline Undecided & 23 & 8.2 & 7 & 3.9 & 30 & 6.5 & 18 & 16.6 & 48 & 8.4 \\
\hline Disagree & 98 & 34.5 & 81 & 43.5 & 179 & 38.1 & 41 & 37.2 & 220 & 37.9 \\
\hline Strongly Disagree & 22 & 7.7 & 39 & 20.9 & 61 & 12.9 & 42 & 38.1 & 103 & 17.7 \\
\hline TOTAL & $\mathbf{2 8 4}$ & $\mathbf{1 0 0}$ & $\mathbf{1 8 6}$ & $\mathbf{1 0 0}$ & $\mathbf{4 7 0}$ & $\mathbf{1 0 0}$ & $\mathbf{1 1 0}$ & $\mathbf{1 0 0}$ & $\mathbf{5 8 0}$ & $\mathbf{1 0 0}$ \\
\hline
\end{tabular}

Source: Field work, 2019

From Table 7, about $42.5 \%$ of respondents from NBC and $8.1 \%$ from Camela Vegetable Oil Company Ltd agree that outsourcing support activities contribute to organizational performance while $51 \%$ of the respondents from NBC and $75.3 \%$ of the respondents from Camela Vegetable Oil Company Ltd disagree. Those interviewed agree that outsourcing support activities like haulage, logistics and transportation of both finished goods and raw materials have greatly contributed to their organizations' performance. The head of haulage department pointed out that payments to the logistics companies are made based on the quantity of goods delivered which wasn't what was obtainable when those support activities were done in house. He added that it has helped the organizations to save cost which invariably improved performance. The notable high percentage of disagreement on the positive effect of outsourcing support activities on organizational performance could be attributable to pity felt for their colleagues who lost their jobs when the transportation activities of NBC was contracted out to another company. The head of warehousing/distribution of NBC in his words noted that:

"some employees disagree that outsourcing support activities like transportation and haulage has contributed to the organizations' performance, because some of their colleagues lost their jobs as a result of that outsourcing', (Male, 47years old HOD, Warehousing/Distribution, NBC).

Table 8: Responses on Whether the Organizations of Study Outsource their Accounting Activities

\begin{tabular}{|l|l|l|l|l|l|l|l|l|l|l|}
\hline & \multicolumn{9}{|c|}{ NBC PLC } & \multicolumn{3}{c|}{ CAMELA } & \multicolumn{2}{c|}{ TOTAL } \\
\hline \multicolumn{1}{|c|}{ Options } & PER & $\%$ & TEM & $\%$ & TOT & $\%$ & NO. & $\%$ & TOT & \% \\
\hline Strongly Agree & 23 & 8.0 & 14 & 7.5 & 37 & 7.8 & - & - & 37 & 6.3 \\
& & & & & & & & & & \\
\hline Agree & 17 & 6.0 & 52 & 27.9 & 69 & 14.6 & - & - & 69 & 11.9 \\
\hline Undecided & 32 & 11.4 & 6 & 3.4 & 38 & 8.3 & 10 & 9.1 & 48 & 8.4 \\
\hline Disagree & 152 & 53.5 & 79 & 42.4 & 231 & 49.1 & 41 & 37.3 & 272 & 46.9 \\
\hline Strongly Disagree & 60 & 21.1 & 35 & 18.8 & 95 & 20.2 & 59 & 53.6 & 154 & 26.5 \\
\hline TOTAL & $\mathbf{2 8 4}$ & $\mathbf{1 0 0}$ & $\mathbf{1 8 6}$ & $\mathbf{1 0 0}$ & $\mathbf{4 7 0}$ & $\mathbf{1 0 0}$ & $\mathbf{1 1 0}$ & $\mathbf{1 0 0}$ & $\mathbf{5 8 0}$ & $\mathbf{1 0 0}$ \\
\hline
\end{tabular}

Source: Research 2019

Table 8 above reveals that $69.3 \%$ and $90.9 \%$ of respondents from NBC and Camela Vegetable Oil respectively disagree that their organizations outsource their accounting activities. In total, $73.4 \%$ of the respondents disagree, $17.9 \%$ agree while $8.4 \%$ are undecided. This shows that though, accounting activities are considered as non-core, they still form an integral part of an organization's operational capabilities and so are considered better handled in-house. This view is further buttressed by the heads of the finance departments of both organizations.

\subsection{Test of Hypotheses}

Hypothesis 1:

$\mathrm{H}_{1}$ : Outsourcing back office activities has a significant positive effect on organizational performance.

$\mathrm{H}_{\mathrm{o}}$ : Outsourcing back office activities has no significant positive effect on organizational performance.

(Table 5 was used to test hypothesis 1) 
Table 9: Computation of Chi-square Test for Hypothesis 1

\begin{tabular}{|l|l|l|l|l|l|}
\hline Options & $\begin{array}{l}\text { Observed } \\
\text { Frequency } \\
\text { O }\end{array}$ & $\begin{array}{l}\text { Expected } \\
\text { Frequency } \\
\text { E }\end{array}$ & $\begin{array}{l}\text { Deviation } \\
\text { O- E }\end{array}$ & $\begin{array}{l}\text { Deviation } \\
\text { Squared } \\
(\mathbf{O}-\mathbf{E})^{2}\end{array}$ & $\begin{array}{l}\text { Deviation Squared } \\
\text { and Weighted } \\
(\mathbf{O}-\mathbf{E})^{2}\end{array}$ \\
\hline Agree & 431 & 193.3 & 237.7 & $\mathbf{5 6 5 0 1 . 3}$ & $\mathbf{2 9 2 . 3}$ \\
\hline Undecided & $\mathbf{8 7}$ & 193.3 & -106.3 & 11299.7 & $\mathbf{5 8 . 5}$ \\
\hline Disagree & 62 & 193.3 & -131.3 & 17239.7 & $\mathbf{8 9 . 2}$ \\
\hline TOTAL & $\mathbf{5 8 0}$ & & & & $\mathbf{4 4 0}$ \\
\hline
\end{tabular}

Level of significance: 0.05

df: 4

$x^{2}$ calculated: 440

$x^{2}$ table value: 9.488

Here, $\mathrm{H}_{\mathrm{o}}$ is rejected and $\mathrm{H}_{1}$ accepted because the calculated chi-square $\left(x^{2}\right)$ is greater than the table chi-square.

This means that outsourcing back office activities has a significant positive effect on organizational performance.

Hypothesis 2:

$\mathrm{H}_{1}$ : Outsourcing primary activities has a positive relationship with organisational performance

$\mathrm{H}_{\mathrm{o}}$ : Outsourcing primary activities has no positive relationship with organizational performance. (Table 6 was used to test hypothesis 2)

Table 10: Computation of Chi Square Test for Hypothesis 2

\begin{tabular}{|l|l|l|l|l|l|}
\hline Options & $\begin{array}{l}\text { Observed } \\
\text { Frequency } \\
\text { O }\end{array}$ & $\begin{array}{l}\text { Expected } \\
\text { Frequency } \\
\text { E }\end{array}$ & $\begin{array}{l}\text { Deviation } \\
\text { O- E }\end{array}$ & $\begin{array}{l}\text { Deviation } \\
\text { Squared } \\
(\text { O }- \text { E })^{2}\end{array}$ & $\begin{array}{l}\text { Deviation Squared } \\
\text { and Weighted } \\
(\mathbf{O}-\mathbf{E})^{2}\end{array}$ \\
\hline Agree & 442 & 193.3 & 248.7 & 61851.7 & $\mathbf{3 1 9 . 9}$ \\
\hline Undecided & 60 & 193.3 & -133.3 & 17768.9 & 91.9 \\
\hline Disagree & 78 & 193.3 & -115.3 & 13294.1 & $\mathbf{6 8 . 8}$ \\
\hline TOTAL & $\mathbf{5 8 0}$ & & & & $\mathbf{4 8 0 . 6}$ \\
\hline
\end{tabular}

Level of significance: 0.05

df: 4

$x^{2}$ calculated: 480.6

$x^{2}$ table value: 9.488

Here, $\mathrm{H}_{\mathrm{o}}$ is rejected and $\mathrm{H}_{1}$ accepted since calculated chi-square is greater than the table chi-square. Hence, outsourcing of primary activities has a positive relationship with organizational performance.

\subsection{Discussion of Findings}

Analysis of data contained in the background information and characteristics of the respondents shows that majority of the respondents are males. However, that $36.2 \%$ of the respondents are females concurs with the view of Ramsaran and Price (2003) that multinational corporations actively recruit women into the labour process by establishing production plants in developing countries as part of their global commodity chains. Findings revealed that majority of the respondents (35.2\%) fall between the ages of 31-40. Being relatively young and of the new information technology generation, curiously exploring new opportunities and grounds, this class of workers desires to achieve certain goals both in the organizational environment and their personal life. As such, they are desirous of using the new technology, such as the internet, afforded by globalization to carry out their tasks and work delivery. Thus, managing this breed of workers requires a paradigm shift from archaic and obsolete practices to the emerging work trend. This view is buttressed by Iheriohanma (2008) who observes that through the exposure of information technology, the Nigerian worker is exposed to workplace trends like their counterparts the world over and now exerts a demand on rising shift from just earning a living to greater interest in a more satisfying and fulfilling work experience. It was equally revealed that the organizations have a highly literate and knowledgeable workforce if we use their educational qualification as shown in Table 4 as a yardstick for such consideration. This implies that the organizations will have the challenge of effectively managing a highly discerning, knowledgeable workforce in this era of emerging work trends, since according to Mohammad, Muslim, Ifthekar and Sulaiman 
(2009), most of the emerging work trends have challenges that do not guarantee employee motivation that can lead to increased job performance. Moreover, the trend now is organizational knowledge management and knowledgeable workers are needed.

Table 5 reveals that employees of both organizations agree that their organizations outsource some of their activities to other organizations. The heads of departments interviewed from the organizations listed security, cleaning, maintenance, transportation, staff health, staff welfare, production, canteen, fabrication of machines and safety and health as some of the jobs outsourced. According to them, the organizations get excellent services from these companies to whom these jobs are outsourced which help in sustaining improved productivity. This shows that these organizations are aware of this work trend and its numerous benefits. Productivity remains a dominant variable and factor in performance, and at times, both concepts are confused in usage. Productivity is the quantum description of the quantitative nature of performance. On the other, performance, as a holistic view of an organization's predetermined goals, describes the qualitative processes and application of efficiency and effectiveness as strategies to productivity. Performance describes the organization's stand on efficiency, quality products and services, effectiveness and timeliness in production and delivery, and most importantly profitability. Organizations cannot sacrifice performance at the altar of productivity nor down-play productivity while pursuing performance. Without performance, quality of productivity - in terms of goods and services - is lowered and the organization is vulnerable to liability exposure and probably loses credence with customers and stakeholders.

Table 6 reveals that there is a general agreement from both organizations that outsourcing back office activities improves performance. From the responses from the interviewees, this research found that the organizations outsource back office activities such as, security and cleaning services. Contracting out these services to organizations who can perform them better decrease the cost of running the organizations, considering that these services are practically subsidiary in nature; thus, it enables the organizations focus on their core areas (Agburu et al, (2017), encouraging them to engage in areas of comparative competences and advantages. Findings from Hypothesis 1 which states that outsourcing back office activities has a significant positive effect on organizational performance goes further to buttress the efficacy of outsourcing back office activities. This finding is further supported by the core competency theory as propounded by Prahalad and Hamel which stipulates that organizations benefit more when resources are channelled towards core activities while the non-core activities such as back office activities are contracted out (Prahalad \& Hamel, 1990).

Table 7 reveals that there is a general consensus about outsourcing of primary activities improving performance in both organizations. This shows that an organization's performance level can be enhanced by outsourcing the primary activities. Those interviewed in NBC Owerri plant highlighted the primary activities outsourced to include production of bottles, pet cokes, water and juice while fabrication is outsourced by Camela Vegetable Company. All the interviewees equally agree that outsourcing of primary activities has a positive effect on organizational performance. Though this is in concurrence with the result of test of hypothesis 2 which states that outsourcing primary activities has a positive relationship with organizational performance, it is in contrast with the view of proponents of core competency theory which stresses that the primary activities which fall within the core area of operation of organizations should be retained in-house and so carried out by the organization itself. It rather supports the transaction cost theory as noted by Yalokwu (2006) in Agburu et al, (2017) which emphasizes on the cost of operation and so states that organizations should contract or subcontract their operations if such can be done cheaper and or better by an outside vendor. Agburu et al, (2017) avers that there is higher level of outsourcing in primary activities in relatively low economic countries like Nigeria unlike what is obtainable in developed and developing countries like Sweden.

From Table 8, it was observed that outsourcing support activities contribute to organizational performance. Those interviewed agree that outsourcing support activities like haulage, logistics and transportation of both finished goods and raw materials which are parts of support activities have greatly contributed to their organizations performance. Agreements in the contracts with these logistics companies are made to reflect payments to be made based on the quantity of goods delivered which wasn't what was obtainable when those support activities were not outsourced. It has helped the organization to save cost which invariably improves performance. The notable percentage of disagreement on the positive effect of support activities on organizational performance is attributable to pity felt for their colleagues who lost their jobs when the transportation activities of NBC was contracted out to another company. Hence, care should be taken while outsourcing so that it will not only be the organization that it is impacting positively on at the detriment of the employees. Research on organization reform and work stress has suggested that outsourcing can trigger events harmful to employee work attitudes (Isabella, 1993) and may create a big problem from the workers themselves, as they might become afraid of losing their jobs (Malhorta, 1997). This affects the continuance commitment of the employees. 
Table 9 reveals that respondents disagree that their organizations outsource their accounting activities. This shows that though, accounting activities are considered as non-core, they still form an integral part of an organization's operational capabilities and so are considered better handled in-house. Interviewees indicate that though financial reporting is done in-house however, the services of external auditor are employed when needed.

\subsection{Conclusion}

From results of this research, it is concluded that outsourcing is not peculiar to only multinational companies, indigenous companies in Nigeria do not only outsource some of their activities, they equally attest to the efficacy of such outsourcing strategies on improved organizational performance. Though there is evidence of ample utilization of such outsourcing strategies such as back office activities (security services, cleaning services); primary activities (manufacturing, production and fabrication); and, support activities (haulage/ transportation), the accounting activities (such as financial reporting, tax processing) are only outsourced for auditing. However, there is need for organizations to be very strategic in their utilization of outsourcing activities to ensure that it is not to the advantage of the organization and at the detriment of the employees. This might breed bad blood and lead to sabotage and espionage (affective and continuance commitment of employees) to the detriment of the organizations in the long run. Furthermore, the research was able to garner knowledge of the outsourcing of core activities like production (as against accounting activities) and its positive effects on organizational performance. This calls to question the insufficiency of the core competency theory in explaining the outsourcing decision in terms of strategic choice and implementation.

\subsection{Recommendations}

The fierce competition globally has made it pertinent for organizations to radically alter and initiate new workplace trends that will provide for improved and sustainable performance for their organizations. Nigeria, as a part of the global village, is not exempt in this quest. Outsourcing as a strategy is highly recommended to both indigenous and multinational organizations in Nigeria as the back office, primary and supporting outsourcing activities have been shown to be of positive effect on organizational performance. Outsourcing encourages healthy competition, comparative competence and advantage, especially in the management of resources, and it is therefore recommended for all organizations in this competitive global economic environment for improved productivity and performance.

\subsection{Suggestions for Further Study}

The theme of this study has a lot of relevance for modern day organizations and can have prescriptive value for other organizations operating in a competitive global economic environment. However, there seems to be paucity of research and literature on this theme within the Nigerian environment. Thus, there is need to investigate further on how to effectively utilize outsourcing strategies because of the increasing use of arrangements and the unfamiliar complexity associated with it, especially in developing countries. It is worthy of note that, though there are evidences of outsourcing by organizations in Nigeria, there is paucity of empirical works supporting it.

\section{References}

Abbott, J. (2003). Does employee satisfaction matter? A study to determine whether low employee morale affects customer satisfaction and profits in the business-to-business sector, Journal of Communication Management, 7(4): 333-339

Agranoff, R. (2006). Inside collaborative networks: Ten lessons for public managers. Public Administration Review, 66: 56-65

Agburu, J.I, Anza, N. C., \& Iyortsuun, A. S. (2017). Effect of outsourcing strategies on the performance of small and medium scale enterprises (SMEs) Journal of Global Entrepreneurship Research, 7: 26

Akewushola, S. \& Elegbede, W. (2013). Outsourcing strategy and organizational performance: Empirical evidence from Nigeria manufacturing sector, European Scientific Journal. 9(19)

Amirkhanyan, A. A., Kim, H. J., \& Lambright, K. T. (2014). The performance puzzle: Understanding the factors influencing alternative dimensions and views of performance. Journal of Public Administration Research and Theory, 24: 1-34

Andersen, L. B., Boesen, A., \& Pedersen, L. H. (2016). Performance in public organizations: Clarifying the conceptual space. Public Administration Review, 76: 852-862

Andrews, R. M., Boyne, G. A., \& Walker, R. M. (2006). Subjective and objective measures of organizational performance: An empirical exploration. In G. A. Boyne, K. J. Meier, L. J. O’Toole, \& R. M. Walker (Eds.), Public service performance: Perspectives on measurement and management. Cambridge, UK: Cambridge University Press, $314-$ 334

Austin-Egole, I. S., Iheriohanma, E.B.J., \& Nwokorie, C. (2020). Flexible working arrangements and organizational performance: An overview, IOSR Journal of Humanities and Social Science (IOSR-JHSS), 25(5 Series 6): 50-59

Awolusi, O.D., (2012). The effects of mergers and acquisitions on business performance in Nigerian banking industry: An empirical analysis, International Journal of Business Performance Management 13(3/4): 366 - 385

Boyne, G. A. (2002). Theme: Local government: Concepts and indicators of local authority performance: An evaluation of the statutory frameworks in England and Wales. Public Money and Management, 2: 17-24 
Brief, A. \& Weiss, H. M., (2002). Organizational behavior: Effect in the workplace, Annual Review of Psychology 53(1): 279307

Bustinza, O, Arias-Aranda, D, \& Gutierrez-Gutierrez, L. (2010). Outsourcing, competitive capabilities and performance: an empirical study in service firms. International Journal of Production Economics, 126(2): 276-288

Cooper-Hakim, A. \& Viswesvaran, C. (2005). The construct of work commitment: testing an integrative framework. Psychological Bulletin, 131: 241-259

Dibbern, J., Goles, T., Hirschheim, R., \& Jayatilaka, B. (2004). Information systems outsourcing: A survey and analysis of the literature, Data Base for Advances in Information Systems 35(4): 6-102

Dominguez, L (2006). The managers's step-by-step guide to outsourcing. Boston: McGraw Hill Companies

Frayer, J.K., Scannell, J.D., \& Thomas, V. (2000). An empirical investigation of global sourcing strategy effectiveness. Journal of Supply Chain Management, 36(2): 29-38

Gilley, K.M., Greer, C.R., \& Rasheed, A.A. (2004). Human resource outsourcing and organizational performance in manufacturing firms. Journal of Business Research, 57(3): 232-240

Gilley, K.M., \& Rasheed, A. (2000). Making more by doing less: An analysis of outsourcing and its effects on firm performance. Journal of Management, 26(4): 763-790

Gupta, M, \& Zheuder, D. (1994). Outsourcing and its impact on operations strategy. Production and Inventory Management Journal, 35(3): 70-76.

Gyemang, D., Aikins, I, Asibey, O, \& Broni, A. (2014). Evaluating the impact of outsourcing of non-Core functions in the hotel industry: A case study of Anita, Noda and golden gate hotels. European Journal of Business and Innovation Research, 2(3): 25-45

Gyeo, R. L., Shinwoo, L., Deanna, M., and Sergio, F. (2019). Outsourcing and organizational performance: The employee perspective. The American Review of Public Administration, 49(8): 1-14

Harrison, D.A., Newman, D.A., \& Roth, P.L., (2006). How important are job attitudes? Meta-analytic comparisons of integrative behavioral outcomes and time sequences, The Academy of Management Journal, 49(2): 305-325

Hayward, C. (2002). Outsourcing the finance function. www.cimaglobal.com/financialmanagement.

Hayes, D.C., Hunton, J.E. \& Reck, J.L. (2000). Information systems outsourcing announcements": investigating the impact of the market value of contract-granting firms. Journal of Information Systems, 14(2): 109-125

Heneman, R.L., (1989). The relationship between supervisory ratings and results oriented measures of performance: A meta analysis, Personnel Psychology, 39(4): 811-826

Huselid, M. A., (1995). The impact of human resource management practices on turnover, productivity, and corporate financial performance, Academy of Management Journal, 38 (3): 635-672

Iaffaldano, M.T., \& Muchinsky, P.M., (1985). Job satisfaction and job performance. A meta-analysis, Psychological Bulletin 97(2): 251-273

Iheriohanma, E.B.J. (2008). The challenges of globalization and poverty in the Third World: A sociological discourse of Nigeria's situation. In J.O Onwuka, (ed). The Third World in sociological perspective. Okigwe: FERP-FASMEN. 241-255.

Irefin I.A, Olateju O.I, \& Hammed G.O, (2012). Effect of outsourcing strategy on project success. Transnational Journal of Science and Technology, 2(6): 128-143

Isaksson, A, \& Lantz, B. (2015). Outsourcing strategies and their impact on financial performance in small manufacturing firms in Sweden. International Journal of Business and Finance Research. 9(4): 11-20

Jae, N.E., Minh, Q.H., Kwok, R.C., \& Shih, M.P., (2000). The Evolution of outsourcing research: What is the next Issue. Proceedings of the 33rd Hawai International Conference on System Sciences.

Jennings, D. (1997). Strategic guidelines for outsourcing decisions. Journal of strategic changes. 32: 85-96

John, D.R. (1999). Consumer socialization of children: A retrospective look at twenty-five years of research, Journal of Consumer Research 26(3): 183-213

Judge, T.A., Thoresen, C.J., Bono, J.E., \& Patton, G.K. (2001). The job satisfaction-job performance relationship, Psychological Bulletin, 127(3): 376-407

Jyoti, J. (2015). Outsourcing and organizational performance: role of cost leadership, differentiation and innovation strategies. In book: sustainable competitive advantage: a road to success, Excel India Publishers, 171-183

Kakabadse, A. \& Kakabadse, N. (2002) Trends in outsourcing: contrasting USA and Europe. European Management Journal, 20: $189-198$

Ketokivi, M. \& Schroeder, R.G., (2003). Manufacturing practices, strategic fit and performance: A routine-based view, International Journal of Operations \& Production Management 24(2): 171-191

Kotabe, M, Murray, J, \& Javalagi, R. (1998). Global sourcing of service and market performance: An empirical investigation. Journal of International Marketing, 6(4): 10-13.

Krell, E. (2007). Outsourcing the finance and accounting functions. CIMA, AICPA and CMA Canada: Management Accounting Guideline.

Kroes, J.R, \& Ghosh, S. (2010). Outsourcing congruence with competitive priorities: Impact on supply chain and firm performance. Journal of Operations Management, 28(2): 124-143.

Kumaran S. (2013). Top 10 benefits of outsourcing accounting and payroll services. https://www.invensis.net/blog/financeand-accounting/top-10-benefits-of-outsourcing-accounting-and-payroll-services.

Leavy, B. (2004). Outsourcing strategies: Opportunities and risks. Strategy and Leadership, 32(6): 20-25.

Lindholst, A. C., Hansen, M. B., Randrup, T. B., Persson, B., \& Kristoffersson, A. (2018). The many outcomes from contracting out: The voice of public managers. Environment and Planning C: Politics and Space, 36: 1046-1067

Meier, K.J, \& O'Toole, L.J. (2012.) Subjective organizational performance and measurement error: common source bias and spurious relationships, Journal of Public Administration Research and Theory, 23(2): 429-456 
Meyer, J.P., Stanley, D.J., Herscovitch, L. \& Topolnytsky, L. (2002). Affective, continuance, and normative commitment to the organization: a meta-analysis of antecedents, correlates, and consequences, Journal of Vocational Behavior 61(1): 20-52

Mohammad, Z. H. Muslim , A. Ifthekhar, A.C. \& Sulaiman, A. (2009). The effects of globalisation, labour flexibilization and national industrial relations system on human resource management. International Business Journal 2(4): 36-45.

Nazeri, A. Gholami, R. \& Rashidi, S. (2012). Outsourcing and its impact on operational performance. Proceedings of the 2012 International Conference on Industrial Engineering and Operations Management Istanbul, Turkey, July 3 - 6, 2012

Nwokocha, I. \& Iheriohanma, E. B. J. (2012) Emerging trends in employee retention strategies in a globalizing economy: Nigeria in focus. Asian Social Science, 8(10): 198 - 207. Website: www.ccsenet.org/ass

Onyeizugbe, C. U., Nduka, S. O. \& Enaihi, S. O. (2019). Flexible time and employee performance in manufacturing firms in Anambra State of Nigeria, European Journal of Business and Innovation Research, 7(5): 42-56

Prahalad, C.K., \& Hamel, G (1990): The core competence of the corporation, Harvard Business Review, 68(3): 79-91.

Quinn, B.J. (2000). Outsourcing innovation: The new engine of growth. Sloan Management Review, 41(14): 13-23.

Rainey, H. G. (2014). Understanding and managing public organizations. San Francisco, CA: Jossey-Bass

Ramsaran, D. \& Price, D.V. (2003). Globalization: A critical framework for understanding contemporary social processes. $\mathrm{http} / / /$ globalization.icaap.org/content/v3.2/02 ramsaran price.html.

Rebernik, M., \& Bradac, B.H. (2006). Cooperation and opportunistic behaviour in transformational outsourcing, Kybernetes 35(7/8): 1005-1013

Reio, T. G., \& Kidd, C. A. (.2006). An Exploration of the Impact of Employee Job Satisfaction, Affect, Job Performance, and Organizational Financial Performance: A Review of the Literature, Semantic scholar, Corpus ID: 2718541

Rho, E., Yun, T., \& Lee, K. B. (2015). Does organizational image matter? Image, identification, and employee behaviors in public and nonprofit organizations, Public Administration Review 75(3): 421-431

Sev, J.T. (2009). An empirical assessment of outsourcing: A strategy for organisational effectiveness in Nigerian corporate sector (a survey of some corporate organisations in Nigeria). An unpublished research survey.

Shiying, L. \& Avery, M. (2009). Alibaba: The inside story behind Jack Ma and the creation of the world's biggest online marketplace, 1st Edition, Harper Business

Singh, S., Darwish, T.K., \& Potočnik, K. (2016). Measuring organizational performance: a case for subjective measures, British Journal of Management, 27(1): 214-224.

Steensma, K.R., \& Corley, K.G. (2000). On the performance of technology-sourcing partnerships: The interaction between partner interdependence and technology attributes. Academy of Management Journal, 43(6): 1045-1067.

Stroh, L.K. \& Treehuboff, D. (2003). Outsourcing hr functions: when - and when not - to go outside, Journal of Leadership \& Organizational Studies 10(1): 19-28

Suraju, R.F. \& Hamed, A.B. (2013). Outsourcing services as a strategic tool for organizational performance: An exploratory study of Nigerian food, beverage, and tobacco industry. Journal of Management Policies and Practices 1(1): 0120.

Task Us (2014). Outsourcing back office operations. https://www.taskus.com/blog/outsourcing-back-office-operations.

Van Slyke, D. M. (2009). Collaboration and relational contracting. In R. O'Leary \& L. B. Bingham (Eds.), The collaborative public manager, Washington, DC: Georgetown University,137-156.

Vrangbæk, K., Petersen, O. H., \& Hjelmar, U. (2015). Is contracting out good or bad for employees? A review of international experience. Review of Public Personnel Administration, 35: 3-23.

Yalokwu, P.O. (2006). Fundamentals of management. Edition, Lagos: Africa Centre for Management.

Yeboah, A. (2013). The relationship between outsourcing and organizational performance. European Journal of Business and Management, 5(2): 2222-2839.

Ying, H. (2012). Transitioning Challenges Faced by Chinese Graduate Students, Sage Journals, 23(3): 138-147

Vij, S., \& Bedi, H.S. (2016). Are subjective business performance measures justified? International Journal of Productivity and Performance Management 65(5): 603-621 